\title{
ANALYSIS OF GEOGRAPHIC DISTANCE EFFECTS ON INTERNATIONAL TRADE FLOWS AS A PUBLIC POLICY: EVIDENCE FROM EAC AND NAFTA COUNTRIES.
}

\author{
Laetitia Byukusenge $^{1}$, Song Wei ${ }^{1}$, Delphine Tuyishime ${ }^{1}$ \\ ${ }^{1}$ School of Public Affairs, University of Science and Technology of China, Hefei, China \\ laety@mail.ustc.edu.cn,songwei@ustc.edu.cn, delfishe@gmail.com
}

\begin{abstract}
Previous studies have shown that the geographic distance is among the factors that can typically results in diminished trade flows between two or more countries. As the international trade is one among the public policies, the governments of countries have to take control policies about their imports and exports after signing some trade contracts or agreements of eliminating trade barriers between trade countries. This paper analyzes and compares how the geographic distance affects the international trade flows of developed and developing countries' economies and becomes the obstacle to the developing countries to achieve their objectives and goals in eliminating trade barriers between their trading partners. The gravity model with panel data sets for period of 2008 to 2011 are used to determine the geographic distance effects in those countries.

The sample size is bilateral trade flows of eight developing countries with lower income of EAC and two developed countries and one developing country with middle income of NAFTA. The study discovers that the various factors influence the geographic distance effects on international trade flows of developed and developing countries in different ways. This paper recommends that the signed policies between countries should be observed, maintained and followed in order to achieve expected objectives.
\end{abstract}

Keywords: Bilateral trade flows; EAC; Geographic distance; International trade; NAFTA, Public Policies.

\section{ACADEMIC DISCIPLINE AND SUB-DISCIPLINES}

Public Administration and economics administration

\section{SUBJECT CLASSIFICATION}

Analysis of economic and Public Administration Policies

\section{TYPE (METHOD/APPROACH)}

Gravity model and Panel Data Estimations (Econometrics)

\section{Council for Innovative Research}

Peer Review Research Publishing System

JOURNAL: INTERNATIONAL JOURNAL OF MANAGEMENT \& INFORMATION TECHNOLOGY

Vol. 10, No.10

editorsijmit@gmail.com

www.ijmit.com 


\section{INTRODUCTION}

International trade has been increasing in the current past period to the extent of that the trade flows are evolving in complex manner and according to the gravity model, the neighboring countries trade more between themselves than how they trade with other countries. However, considering the case of developing countries, there is no evidence of that they trade more among them more than they do with the rest of the world. We are comparing the case of East African Community (EAC) and North American Free Trade Area (NAFTA) since the free trade agreement area and regional block such as NAFTA and EAC respectively are organized between neighboring countries for trade facilitation between member countries. The main goal of EAC is to liberalize and promote cross-border trade among the member states in elimination of all internal tariffs and other charges of equivalent effect on trade amongst partner states. NAFTA was created with the purpose of establishing a trilateral trade bloc in North America and eliminate all remaining duties and quantitative restrictions between country members. NAFTA and EAC both have the objectives. One can say that this is not true and this raise the doubt of thinking that the trends of the trading flows are now the same in developed countries as well as in developing countries. Therefore, taking EAC and NAFTA countries, the current research is about to identify and compare how the geographic distance affects the international trade of developing countries and developed countries. In this paper, the following five questions are addressed:

:-Do the neighboring countries trade in between than how they trade with those of the far away?

-Does geographic distance have the same effects on the flows of international trade in high and middle income countries as well as in low income countries?

-Do the EAC countries trade between themselves more than they trade with other countries? - -Do EAC member states have enough export products to satisfy their economic demand among themselves?

-Is international trade as a public policy respected and followed between countries as geographic distance is concerned?

The current empirical study identifies that international trade is increasing and the flows of trade are shaping in the complex system and one of the main factor to this shape is geographic distance. However, the flows of trade of developed countries are different from the developing one. Therefore, the present research is about to investigate how the geographic distance affects the international trade of a developing country. This research is significant in this sense that it will help to identify the impediments to trade in terms of distance and in giving recommendations in the purpose of enhancing the trade partnership among regional basis of the developing countries. To determine different effects of geographic distance in trading flows, this paper uses gravity model with panel data of mentioned countries downloaded from international trade center (ITC) database and some recommendations are provided in order to have both countries benefiting from their trade.

It is expected that the geographic distance has negative effects on the flow of international trade in developing countries as well as in developed ones and this results in the fact that neighboring countries like EAC Countries are the most trading partners.

The rest of the paper is organized as follows: In section 2, related works are presented, in section 3 , data and their sources are given, data presentation is shown in section 4 , section 5 presents the proposed econometric model with variables definition, findings are presented in section 6 and finally section 7 concludes the paper with some recommendations.

\section{RELATED WORKS}

According to international trade statistics, developed countries trade between themselves more than developing countries $\mathrm{do}^{[1]}$. Based on the theory of gravity model, this situation is totally different from the predictions of the said model by which the neighboring countries trade more between them because the distance is one of impediments to trade ${ }^{[2]}$.

Gravity model has been defined as the workhorse of international trade and its ability to correctly approximate bilateral trade flows makes it one of the most stable empirical relationships in economics ${ }^{[3]}$. Some researchers concluded that when physical distance between exporter and importer enlarged $1 \%$ of distance, trade flows between them decline $1.1 \%{ }^{[4]}$ Distance increases the cost of international goods and services transactions. In addition to distance, the costs of the cross-border trade are also deterrent and obstacle to trade. Further distance between the two potential trade partner increases bilateral trade costs and reduces the benefits of trade ${ }^{[5]}$. The country which has access to the sea and distance to major markets has a strong impact on shipping costs. There is a trade-off between time and cost in the demand for transport services. Lengthy shipping times impose costs that impede trade. Therefore, importers are willing to pay in order to avoid these costs. Some researchers shows that Higher trade costs significantly impede trade for some, and since the major component of trade costs is undoubtedly the transport component, a better understanding of its

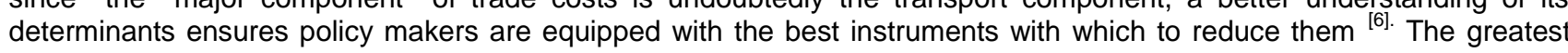
impediments for international trade are: the distance between countries, importers' transportation costs, and if trading partners are landlocked ${ }^{[7]}$.the direct transport costs impede trade in much the same way as tariffs. Empirical evidence shows that freight charges are a crucial determinant of a country's ability to participate in the global economy and ultimately of its export competitiveness. It has been estimated that a $10 \%$ increase in transport costs may reduce trade volumes by more than $20 \%{ }^{[8]}$ and that the decline in transport costs accounts for 8 per cent of average world trade growth in the post-World War II period ${ }^{[9]}$.

This paper considers the comparative and absolute advantage theories as its theoretical framework, as the classic theory 
for non barriers trade between two nations.

\section{DATA AND THEIR SOURCES}

The unbalanced panel data sets (they have a different number of observations between groups in time given) of EAC and NAFTA are analyzed in this study. EAC is mandated by five countries and was at the custom union level of regional economic integration from 2008 until 2011, we take this period as panel data period sets (4years). After this period EAC shifted to the common market level. EAC and, NAFTA members 'countries exports from and imports to their trade partners various goods and services and the total trade values for 2008-2011are analyzed in this paper. In this period, EAC imported products from 84 countries with 264 trade pairs of countries and exported to 106 countries with 268 countries pairs. NAFTA is signed by 3 countries; it imported the products from 42 countries with 72 countries pairs and exports its products to 38 countries with 60 countries pairs. Some country pairs' names are repeated each year and others are not that is why the panel data set is unbalanced. The total value is determined by GDP of EAC and NAFTA countries members, GDP of their trade partners countries, distance between the pair of countries' center and the dummy variables/qualitative variables like common languages, common border between two partners countries, common regional trade agreement (RTA) and to see if one or both trade partners is/are landlocked.

The sources of data used in this paper are obtained as follows: The trade flows for exports and imports are obtained from the international trade center (ITC) database ${ }^{1}$ where the top 200 bilateral flows are analyzed for sample countries for every concerned year. The Gross Domestic Products data are obtained from the World Bank online database ${ }^{2}$. The distance between the importer and exporter's center is obtained from wolfram website ${ }^{3}$. The Common language is when importer and exporter have the same official language, common border is when countries share one border, landlocked countries are countries which have no access to the sea, isolation, and remoteness from world markets and if country is the member of EAC or NAFTA. The reasons of selecting these databases is based on a belief of that they are the best ones containing data on flows of international trade of most of the countries which can contribute maximally to the research.

\section{DATA PRESENTATION}

In this paper, the data is summarized by the four scatter plots drawn using STATA software which shows the relationship between exports and imports, and geographic distance between trading partners. They are presented in 4 different figures as follows.

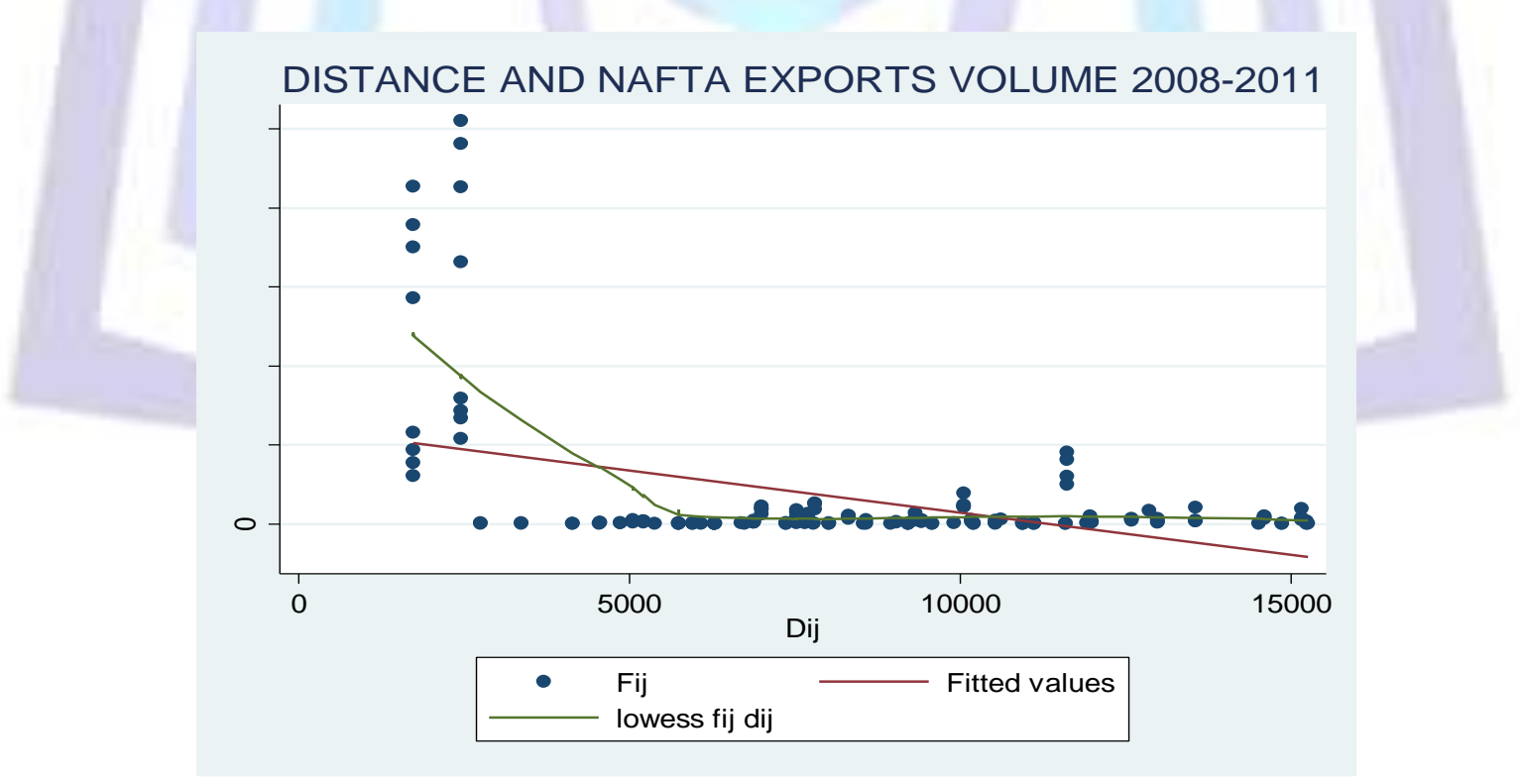

Figure 1: NAFTA Exports and Distance

\footnotetext{
${ }^{1} \mathrm{http} / / \mathrm{www} . \mathrm{macmap} . \mathrm{org} /$

2 http://wdi.worldbank.org

3 http://www.wolframalpha.com/
} 
Figure1 shows the regression (fitted values) and lowest lines between distance $\left(\mathrm{d}_{\mathrm{ij}}\right)$ and total trade volume ( $\left.\mathrm{F}_{\mathrm{ij}}\right)$ for NAFTA total volume exports. It shows that when the distance is low, the total volume exported is high; when the geographic distance increased the NAFTA total volume decreased. The distance and NAFTA total exports have the negative relationship due to the NAFTA member countries trade agreement.

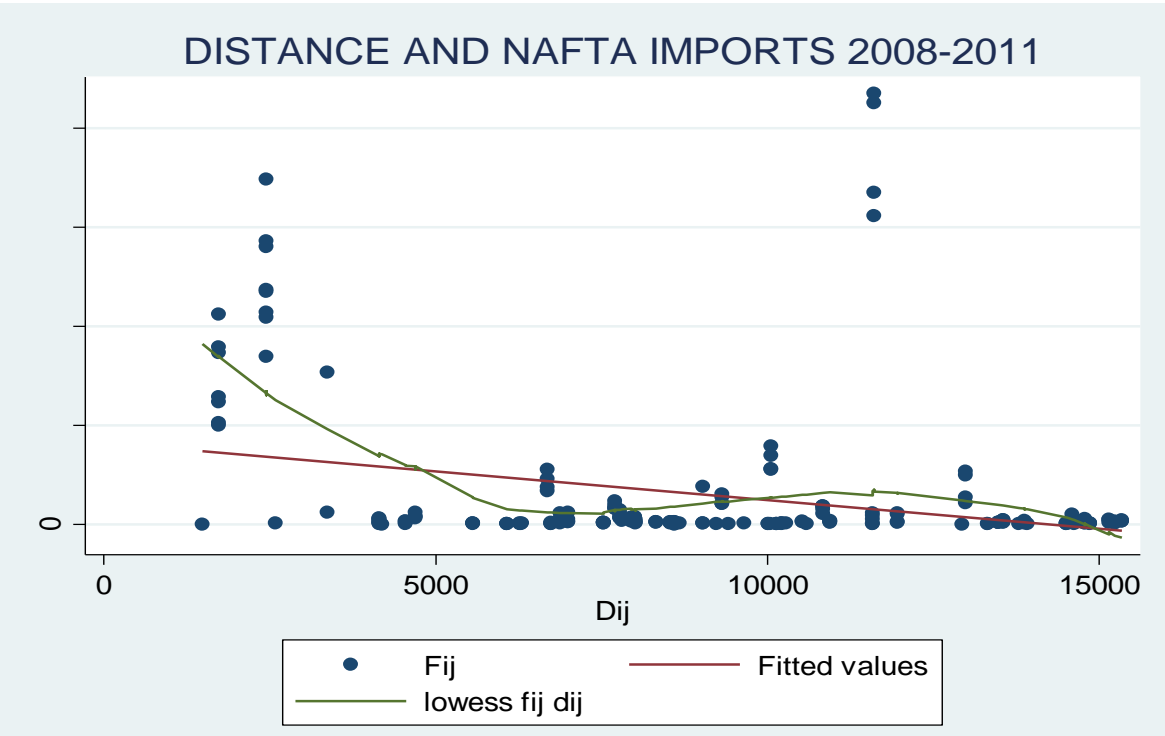

Figure 2: NAFTA Imports and the Distance between Trade Partners

Figure2 shows that NAFTA imports more from their neibhoring countries but sometime it imports more from non neibhoring countries. The imports data shows that United States of America imported more from China in 2010 and 2011 and the geographic distance between them is high but in general NAFTA imports are from the member countries themeselves. To increase imports from non nebghoring countries for developed countries is considered as the government policy or public policy of getting law materials for domestic firms or establishing new technology in country. The fitted values line is the regression line and the lowess $f_{i j} d_{i j}$ is the lowess line between total volume imported $\left(f_{i j}\right)$ and distance between the distance between trading partners'centers.

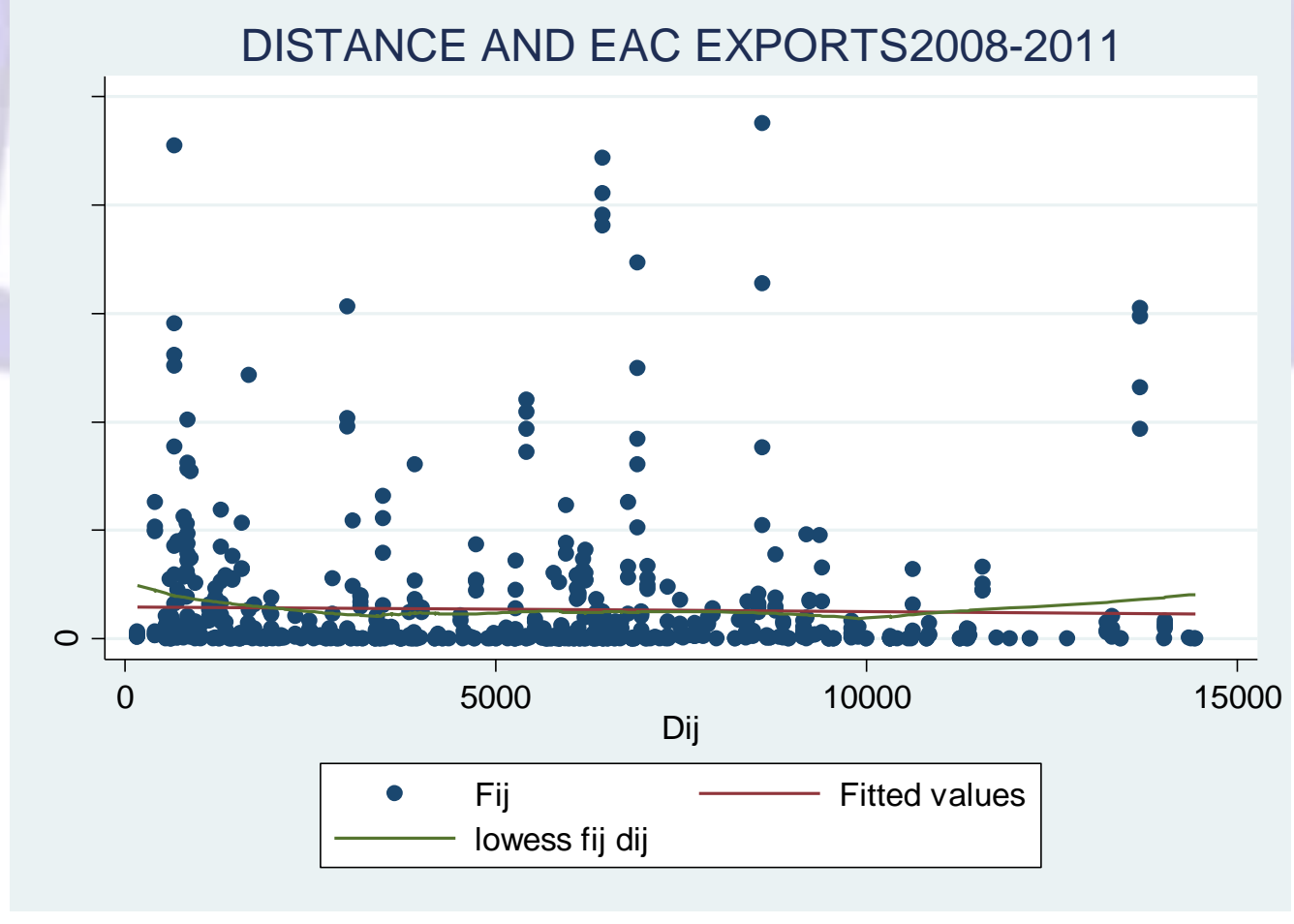

Figure 3 : EAC Exports and Geographic Distance 
Figure3 shows the geographic distance $\left(\mathrm{d}_{\mathrm{ij}}\right)$ in $\mathrm{km}$ on $\mathrm{X}$ axis and total trade volume exported $\left(\mathrm{F}_{\mathrm{ij}}\right)$ in US dollars on $\mathrm{Y}$ axis. The smallest distance is the distance between Rwanda and Burundi which is $166 \mathrm{~km}$ but those countries do not trade more between them. The relationship between trade volume exported and the distance is unexplained while there are free trade agreements between EAC member countries as custom union economic integration. The regression line is the fitted values line. The EAC member countries generally have lower trade volume for exports. In general, EAC member countries exports the natural resources and agricultural products from their mining and agricultural sectors as the raw materials to the industries of transition and developed countries. They do not care about the geographic distance effects on the international trade, they exports everywhere they get the market.

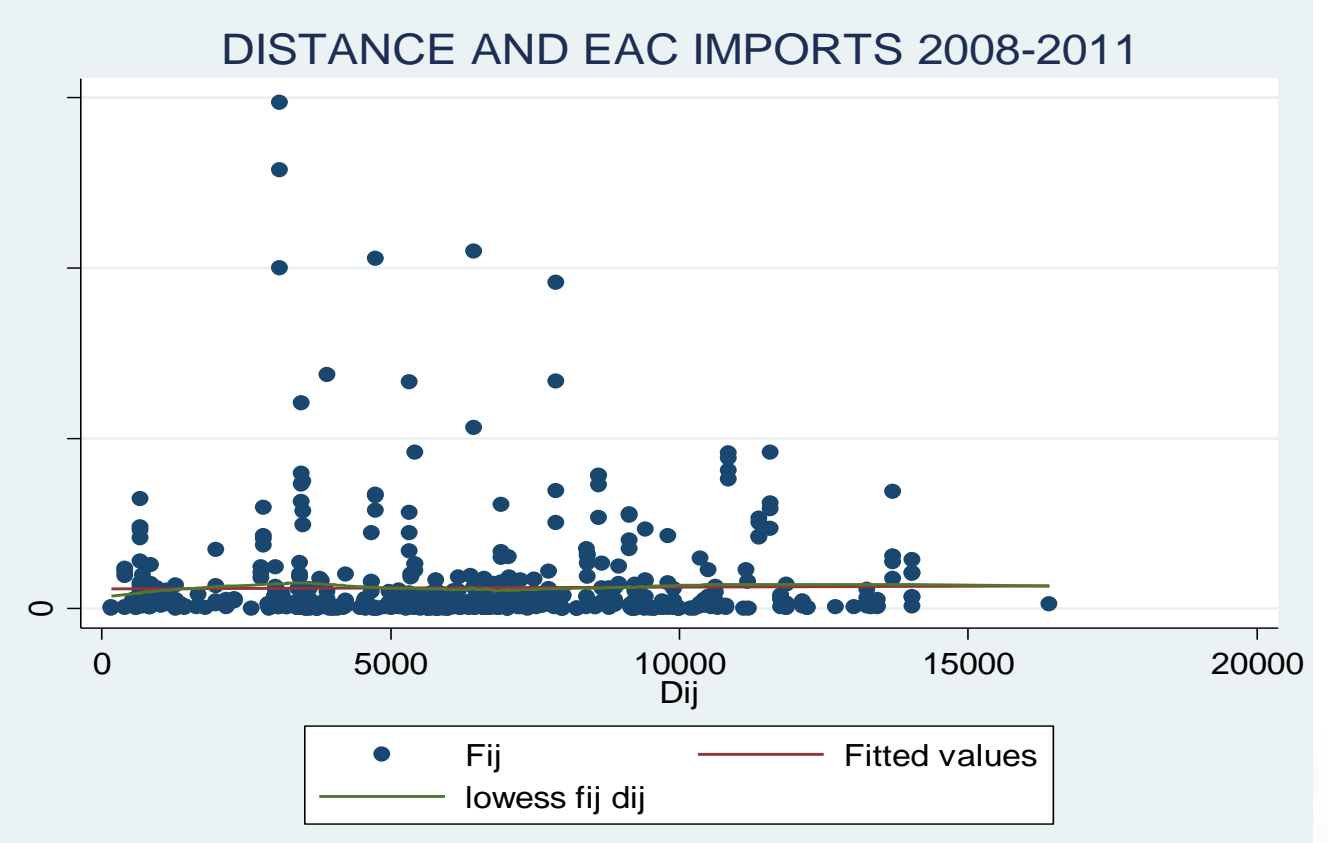

Figure 4: EAC Imports and Geographic Distance

Figure4 shows that the geographic distance on $\mathrm{X}$ axis and total trade volume between trading group countries on $\mathrm{Y}$ axis, the fitted values line is the regression line. The total trade volume imported is greater than the total volume exported. EAC imports more from United Arab Emirates (ARE) with $3075 \mathrm{~km}$ distance from Kenya's center. The distance between EAC members is not long distance; the highest is the distance between Burundi and Kenya countries' centers which is $1020 \mathrm{~km}$. More EAC member countries imports are from the rest of the world or non member countries and less from the member countries.

\section{PROPOSED ECONOMETRIC MODEL}

In this study, the gravity model is built to analyze and compare the geographic distance effects on international trade flows between EAC and NAFTA.

The model is written as follows:

$\ln F_{\mathrm{ij}}=B_{0}+B_{1} \ln M_{\mathrm{i}}+B_{2} \ln M_{\mathrm{j}}+B_{3} \ln d_{\mathrm{ji}}+B_{4} \operatorname{landlock}_{\mathrm{ij}}+B_{5} \operatorname{lang}_{\mathrm{ij}}+B_{6}$ bord $_{\mathrm{ij}}+B_{7} R T A_{\mathrm{ij}}+e_{\mathrm{ij}}$

Equation 1

Where $\beta_{0}$ to $\beta_{7}$ are coefficients or parameters to be estimated,

$\ln F_{i j}$ represents the logarithm of volume of trade flows from country $i$ to country $j$, in case EAC or NAFTA member countries exported goods and services to other countries or within themselves; or it represents volume of trade flows to country ${ }_{i}$ from country $j_{j}$, in case EAC and NAFTA member countries imported goods and services from other countries or within themselves. In $M_{i}$ typically represents the logarithm of GDP of EAC and NAFTA member countries;

In $M_{j}$ typically represent the logarithm of GDP of countries $\mathbf{j}_{\mathbf{j}}$,

Ind $d_{i j}$ denotes the logarithm of distance between the two trading partner's center,

bordij: when exporters and importers share or have the same common land border,

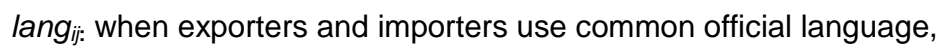

landlock $k_{i j}$ whether one trading partner is landlocked countries or both of the trading partners are a landlocked countries, 


\section{ISSN 2278-5612}

$R T A_{i j:}$ whether both exporters and importers countries are belonging in EAC or NAFTA member countries.

$e_{i j}$ denotes error term.

\subsection{NAFTA estimation Methods' Tests}

With NAFTA exports (2008-2011), in testing the suitable model between the random and fixed effects estimates two hypothesis are suggested Ho: random effects model is appropriate, $\mathrm{H} 1$ : fixed effects model is appropriate. hausman test shows us that the random effects estimator is suitable after rejecting the null hypothesis with fixed effects and prob $>$ ch2 $=$ 0.98 which is $98 \%$ and greater than $5 \%$ or 0.05 . After this test (hausman test), we would decide the suitable model between random effects and pooled OLS estimations, with the following hypothesis: Null hypothesis (Ho): Pooled OLS regression model is appropriate, $\mathrm{H} 1$ or alternative hypothesis: random effects regression model is appropriate. Here we test them with Breusch-Pagan Lagrange multiplier (LM) test. This test shows that the random effect is suitable than pooled OLS estimation model due to pro $>$ ch2 $=0.000$ which less than 0.05 . Both tests (Hausman test and breusch-pagan Lagrange Multiplier) show that the random effects model is more suitable for NAFTA exports data ${ }^{[10]}$.So NAFTA for exports data; the random effects GLS regression model has the following equation:

$\ln F_{\mathrm{ij}}=B_{0}+B_{1} \ln M_{\mathrm{i}}+B_{2} \ln M_{\mathrm{j}}+B_{3} \ln d_{\mathrm{ji}}+B_{4}$ landlock $_{\mathrm{ij}}+B_{5} \operatorname{lang}_{\mathrm{ij}}+B_{\mathbf{6}}$ bord $_{\mathrm{ij}}+B_{7} R T A_{\mathrm{ij}}+e_{\mathrm{ij}}$

Equation 2

For NAFTA imports (2008-2011) also it is also needed to decide which regression model or estimation is appropriate. Ho: random effects model is appropriate, $\mathrm{H} 1$ : fixed effects model is appropriate. Hausman test is shown that the fixed effects estimation is suitable than random affects where prob $>$ ch2 $=0.0001$ and which is less than 0.05 . For NAFTA imports, the fixed effects estimation is suitable. Fixed Effects using least squares dummy variable model (LSDV) in this case, take the following equation:

$$
F_{i j}=B_{0}+B_{1} d_{i j}+B_{2} \operatorname{lang}_{i j}+B_{3} \text { bord }_{i j}+B_{4} R T A_{i j}+e_{i j}
$$

Equation 3

\subsection{EAC Estimation Techniques' Tests}

For EAC exports for period of 2008 to 2011, the null hypothesis is rejected because prob>ch2 is 0.9966 which is greater than 0.05 and the alternative hypothesis is considered, the fixed effects estimation is rejected, the random effects is suitable.

Breusch and Pagan Lagrangian multiplier test, Null hypothesis $(\mathrm{Ho})$ : Pooled OLS regression model is appropriate, $\mathrm{H} 1$ or alternative hypothesis: random effects regression model is appropriate, for random effects regression model also shows that random effects estimation is suitable than pooled OLS estimation because with this test prob > ch2 or probability value is 0.0000 that is why we consider the null hypothesis and reject the alternative hypothesis. The equation4. 1 is also applied for EAC exports.

EAC imports' hausman test, Ho: random effects model is appropriate, $\mathrm{H} 1$ : fixed effects model is appropriate, the null hypothesis is rejected and alternative hypothesis is considered. The fixed effects estimates are rejected, the random effects estimates are considered due to prob > ch2 is 1.0000 which is greater than 0.05 .

In this case, Breusch and Pagan Lagrangian multiplier test shows that we fail to reject the null hypothesis, the random effects estimates are more appropriate than the pooled OLS regression model. The probability value (pro > ch2) in this test is statistically significant with P-value of 0.0000 and is less than 0.05 .

According to hausman and Breusch and Pagan Lagrangian multiplier test, data should be analyzed with the suitable estimates. EAC exports and imports trade flows have the same equation and estimation techniques. The equation 4.1 will be applied to both exports, imports of EAC and for NAFTA exports. (Refer to econometric results tables in appendix A).

\section{FINDINGS}

With the NAFTA exports, the 176 trade countries pairs are observed, and the dependent variable is the trade volume exported by NAFTA member countries to their trade partners in the period of four years (2008-2011). In this case, there is no relationship between trade volume exported and the gross domestic products (GDP) of NAFTA since their probability value is lower than 0.05 but there is a relationship between trade volume and the gross domestic products of NAFTA's importers as their probability value is 0.148 which is greater than 0.05 .

The geographic distance has less influence on NAFTA's exports since Canada, United States and Mexico trade more between them as neighbors and trade less within other countries.

NAFTA exports goods and services to landlocked countries. This has the influence on trade volume since its probability value is 0.223 which is greater than 0.05 . To be a landlocked country means that a lack of territorial access to the sea, isolation, and remoteness from world markets, and results in high transport and transit costs. The common languages between NAFTA and its importers share the effects on trade volume at 0.53 of probability value while NAFTA members have no common language between them. Mexico has Spanish as its official language but Canada and United States of America have English as their common official language. The common border dummy variable does not affect NAFTA trade volume as its probability value is less than 0.05 . Belonging in the same regional trade agreement also influences trade volume for exports. 
With NAFTA imports, the 201 country pairs are also observed, the trade between the non landlocked countries reduces transport expenses, NAFTA country members are not landlocked countries and they trade more between them. NAFTA imports trade volume is highly influenced by landlocked dummy variable. To be in NAFTA increases the trade volume of imports from country members due to free trade agreement signed between them. To have common borders between countries is the same as on exports volume, this dummy variable is correlated with trade volume imported with the probability value of 0.58 .

With EAC imports, the 649 countries group pairs are observed, the GDP of EAC country members and their trade partners has significant influence on the imports trade volume. The distance between two center's countries has also significant influence on EAC imports volume. To be landlocked country does not have the significance influence on trade imports share of EAC. To have the common language and the common border has high significant influence on import shares but to belong in the same regional block has low significant on trade shares.

With EAC exports, the 665 countries pairs are observed, the exporters' and importers' Gross Domestic Products are correlated with exports trade shares in EAC. The geographic distance also is correlated with trade volume, the EAC countries member exports more to the rest country of the world and exports less between themselves. To be landlocked countries is not correlated with the countries' exports trade shares but it influences the trade volume negatively. To have the common language between trade partners is correlated with trade volume between them with the probability value of $44 \%$. To have common border for EAC and its trading partners have significant on its trade exports volume but to belong in the same regional block is not significant on the exports trade share.

\section{CONCLUSION AND RECOMMENDATIONS}

The international trade is the one among the public policies that should have positive impact on the economic growth of countries since it is a control of the international economy of countries but it should be affected by the geographic distance between the trading partners. The geographic distance effects on international trade of developed and developing economy are different based on different factors which influence negatively or positively the international trade between trading partners. The developing countries do not trade more with their neighboring countries since they do not have enough exports products while the neighboring countries need more imports products. The inefficiency of availability of exports products in developing countries causes them to import more from non neighboring countries and the agreement signed between those countries only remain in documents. It was observed that developing countries do not trade much between them; instead they trade with developed countries because they do not have sufficient industries and technology skills for transforming their raw materials into products and then end by sending the low material into developed ones.

The developing countries are recommended to be creative and innovative in technology and science field instead of exporting the natural resources and agricultural products to others countries which are developed and developing with middle economy countries they should transform into finished products themselves through the international technology transfer from those developed countries. And it is also recommended to use the opportunity of being in the same the Economic integrations as they planned in order to trade more among themselves with non-trade barriers policy and with low distance geographic.

Last but not least, the developing countries need to respect and follow their trading agreements in order to attain their objectives, policies and goals sufficiently and effectively.

\section{REFERENCES}

[1] World Trade Organization (WTO), 2012, International trade Statistics report,

[2] Paul R. Krugman, Maurice Obstfeld and Marc J. Melitz,, Pearson 2012, International Economics, Theory \& Policy, 9thEdition, 10-23.

[3] Luca Salvatici, April 2013, the Gravity Model in International Trade, Version 2, AGRODEP Technical Note TN-04, 1-24.

[4] Frankel, J. A., and Rose, A. K. 2002, "An Estimate of the Effect of Common Currencies on Trade and Income”. Qtrly. J. Econ. 117, 437-466.

[5] Thomas Chaney, 2011, the Gravity Equation in International Trade: An Explanation, University of Chicago, Working Paper 19285, JEL No. F1, NBER and CEPR, Cambridge, 1-49.

[6] Patricia Sourdin, Quantifying the impacts of structural reforms on international

transport margins, chapter 3, 71-87.

[7] Dushko Josheski and Risto Fotov, May, 2013"Gravity modeling: International trade and R\&D", International Journal of Business Management and Administration Vol. 2(5), pp. 073-080

[8] Limão, N., and Venables, A. J. 2001, Infrastructure, Geographical Disadvantage, Transport Cost and Trade. World Bank Economic Review, 15, 3, 451-479

[9] Baier SL, Bergsrtand H. 2007 "Do free trade agreements actually increase members' international trade?" Journal of International economics; 71(1): 72-95

[10] Oscar Torres-Reyna, 2007, Panel Data Analysis Fixed and Random Effects using STATA (v.4.2) Data and statistical 
services, Princeton University, 1-40

\section{Appendix A: ECONOMETRIC RESULTS}

a. Random Effects Model as EAC exports Estimation

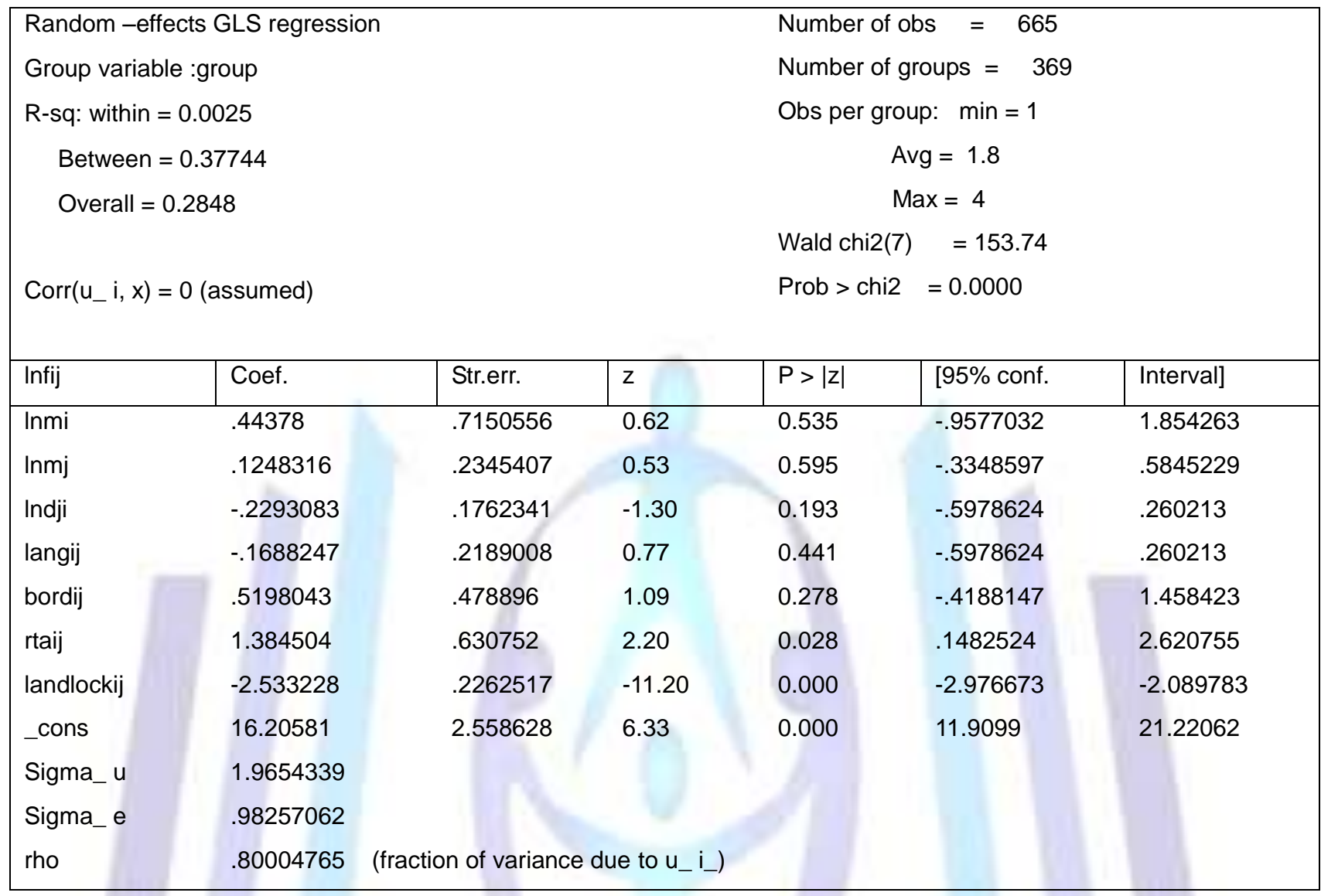

b. Random Effects Model as EAC Imports Estimation

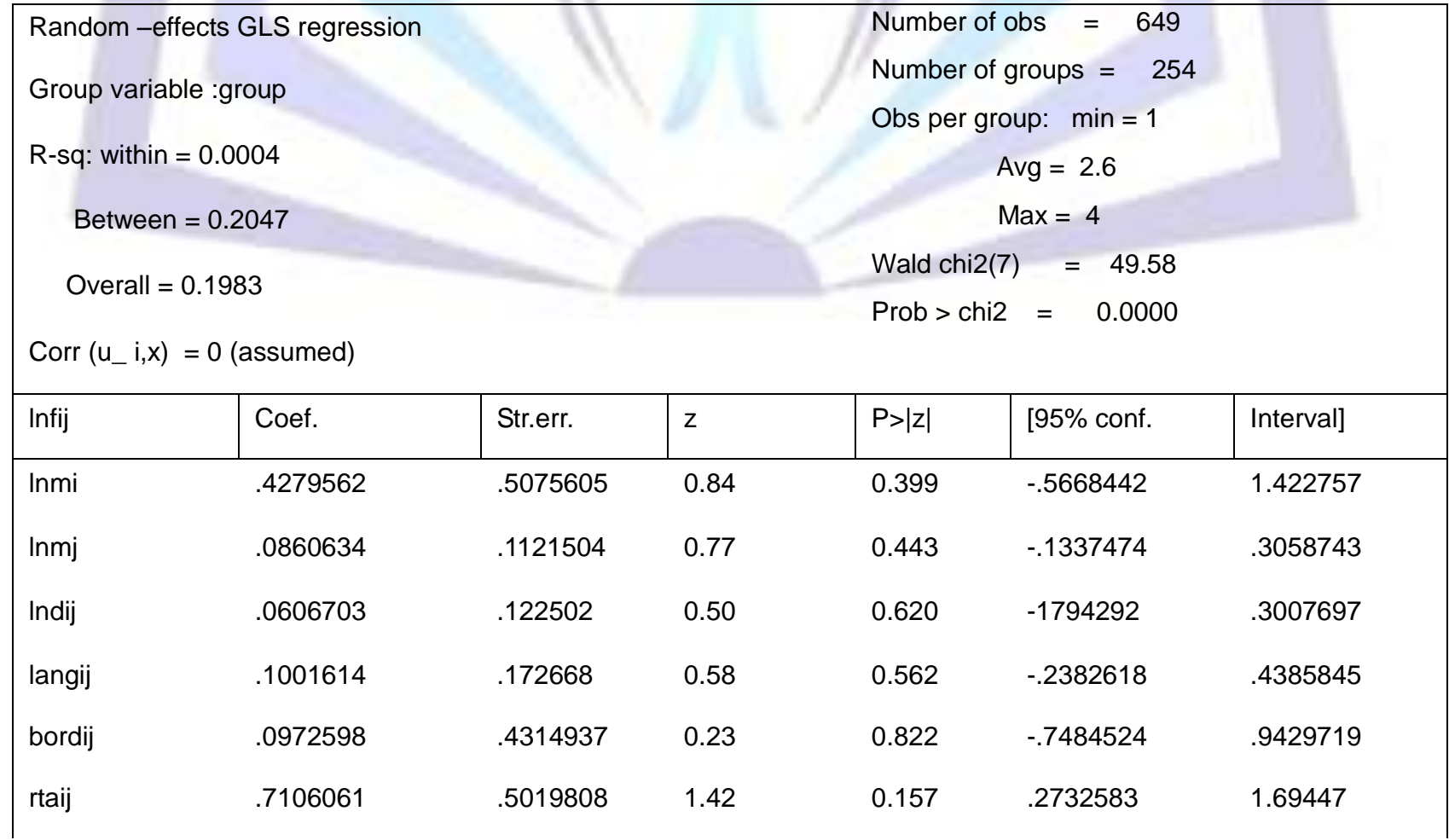




\section{ISSN 2278-5612}

\begin{tabular}{|lllllll|} 
landlockij & -1.237011 & .1876668 & -6.59 & 0.000 & -1.604831 & -.8691907 \\
_cons & 14.82655 & 1.832151 & 8.09 & 0.000 & 11.2356 & 18.4175 \\
Sigma_u & 1.3651543 & & & & & \\
Sigma_e & .79947885 & & & & \\
rho & .74462076 (fraction of variance due to u_i__ & & & \\
\hline
\end{tabular}

c. Random Effects Model as NAFTA exports Estimation

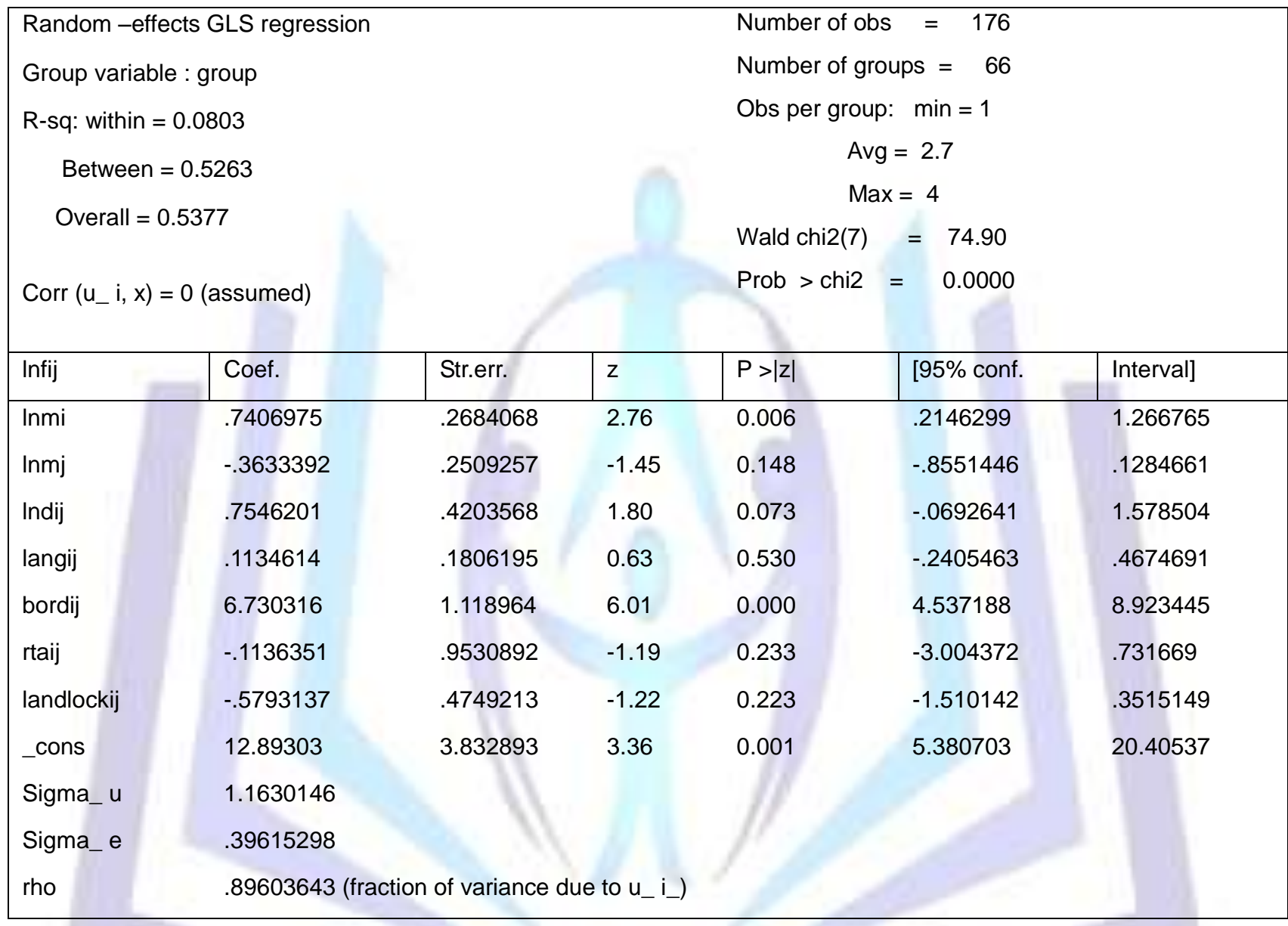

d. Fixed effects model for NAFTA imports

\begin{tabular}{|c|c|c|c|c|c|c|}
\hline \multicolumn{3}{|c|}{ Fixed effects (within)regression } & \multicolumn{4}{|c|}{ Number of obs $=201$} \\
\hline \multicolumn{3}{|c|}{ Group variable: group } & \multicolumn{4}{|c|}{ Number of groups $=72$} \\
\hline \multicolumn{3}{|c|}{ R-sq: within $=0.1452$} & \multicolumn{4}{|c|}{ Obs per group : $\min =1$} \\
\hline \multicolumn{3}{|c|}{ Between $=0.0480$} & \multicolumn{4}{|c|}{ Avg } \\
\hline \multicolumn{3}{|c|}{ Overall $=0.0320$} & \multicolumn{4}{|c|}{ Max } \\
\hline \multicolumn{3}{|c|}{$\operatorname{Corr}(\mathrm{U}-\mathrm{i}, \mathrm{xb})=-0.3352$} & \multicolumn{2}{|c|}{$\begin{array}{l}F(4,125) \\
\text { Prob }>F\end{array}$} & \multicolumn{2}{|l|}{$\begin{array}{l}=5.31 \\
=0.0006\end{array}$} \\
\hline fij & Coef. & Std.err. & $\mathrm{t}$ & $P>|t|$ & [ $95 \%$ conf. & Interval] \\
\hline langij & $-1.52 e+07$ & 3301987 & -4.60 & 0.000 & $-22.17 e+07$ & -8665562 \\
\hline bordij & -2478722 & 4480961 & -0.55 & 0.581 & $-1.13 e+07$ & 6389657 \\
\hline rtaij & -457918.9 & 5009268 & -0.09 & 0.927 & $-1.13 e+07$ & 9456045 \\
\hline
\end{tabular}




\section{ISSN 2278-5612}

\begin{tabular}{|c|c|c|c|c|c|c|}
\hline landlockij & 334572.9 & 6281681 & 0.05 & 0.958 & $-1.21 e+07$ & $1.28 \mathrm{e}+07$ \\
\hline -cons & $1.84 \mathrm{e}+07$ & 1155073 & 15.91 & 0.000 & $1.61 \mathrm{e}+07$ & $2.07 e+07$ \\
\hline Sigma_u & \multicolumn{6}{|l|}{3347443} \\
\hline Sigma_e & \multicolumn{6}{|l|}{7476696.1} \\
\hline rho & \multicolumn{6}{|c|}{.9524856 (fraction of variance due to $\mathrm{u}-\mathrm{i}$ ) } \\
\hline$F$ test that & $F(7$ & 47.88 & $>F=$ & 000 & & \\
\hline
\end{tabular}

